\title{
The Transformation of Law in the Late and Post-Roman World:
}

\section{Introduction}

The history of law in late Antiquity and the early Middle Ages used to offer a repository of certainty. ${ }^{1}$ It is now a field in productive turmoil. ${ }^{2}$ The papers offered here look to increase our sense of uncertainty, to make strange familiar landmarks. However orderly its codifications may appear, law in this period was an unstable resource, no sooner made than remade for new and unexpected purposes.

The briefest of historiographical sketches is in order. We may begin in Germany at the turn of the nineteenth century: scholars in the so-called Historische Rechtsschule set out a whole vision of the past and a programme of scholarship that went with it. ${ }^{3}$ As is well-known, much of their efforts centred on the period of interest to readers of this journal. Their basic typologies of the law-Roman law, Germanic law, Church law -carried with them an account of the end of the ancient world and the beginning of the Middle Ages. Roman law was top down, imposed by the emperor; Germanic law, by contrast, came from below, from the people. The triumph of the latter over the former was a cause for celebration; in this spirit, it was the task of scholars painstakingly to reconstruct the textual traces of the development of the people's law-and so came into being the great series of editions of early medieval legal texts on which we continue to rely.

\footnotetext{
${ }^{1}$ These papers emerge out of a sustained collaboration between Anglophone and German-speaking colleagues. The project owed not a little to the signal contribution of Kate Cooper, and we regret she was unable to offer an essay to this volume. We are grateful to the Fell Fund of the University of Oxford, the Lightbody Fund of Worcester College, Oxford, and the Universities of Berlin, Manchester, and Tübingen for funding to support our meetings. For their comments on this Introduction, my thanks to Marios Costambeys, Alice Raw, and to fellow contributors.

${ }^{2}$ A mood well captured by T. Lambert, Law and Order in Anglo-Saxon England (Oxford, 2017), vii-ix.

${ }^{3}$ On the Rechtsschule, see now G. Dilcher, Die Germanisten und die Historische Rechtsschule : bürgerliche Wissenschaft zwischen Romantik, Realismus und Rationalisierung (Frankfurt, 2017), and H.-P. Haferkamp, Die historische Rechtsschule (Frankfurt, 2018). In English: J. Goeber, Felony and Misdemeanour (New York, 1937), 1-122.
} 
Of course this marriage of History and Law is now dissolved, and the verities flowing from it have long since run into the ground. The idea of 'Germanic law' in particular has evaporated, seen to rely on an untenable, indeed dangerous set of assumptions about the identity of the 'barbarian' peoples who occupied the former western Roman Empire. ${ }^{4}$ German-speaking scholars have led the way here. In 1959, Frantisek Graus called into question the existence of Germanic Treue, the lamost untranslatable concept of peace-making loyalty, seen to be at the core of the social order in the barbarian West. Treue was a shibboleth of the Rechtsschule, which Graus called out as a baseless fiction. He was followed here by Karl Kroeschell, who did not hesitate to draw the wider conclusion that there was a problem with the whole concept of Germanic law. ${ }^{5}$ By the early 1980 s, this scepticism had won the day, and a new generation of scholars turned with fresh energy back to the study of legal manuscripts. ${ }^{6}$

Anglophone scholarship followed suit, both consciously and unconsciously, in repudiating the legacy of the Rechtsschule. Thus in 1986, in The Settlement of Disputes in Early Medieval Europe, a group of like-minded colleagues set out a manifesto for the study of social practice in the post-Roman West. ${ }^{7}$ Law seemed suddenly irrelevant here. The lawcodes supposedly deriving from 'the people' did not feature in the charters recording the arbitration of disputes: these codes were rather an exercise in

\footnotetext{
${ }^{4}$ S. Esders, 'Late Roman Military Law in the Bavarian Law Code', Clio@Thémis, Revue électronique d'histoire du droit 10 (2016), accessible at http://www.cliothemis.com/ offers a survey with fulsome references. .

${ }^{5}$ F. Graus, 'Uber die sogenannte germanische Treue', Historica I (Prague, 1959), 71-121; K. Kroeschell, 'Die Treue in der deutsche Rechtsgeschichte', and 'Germanisches Recht als Forschungsproblem', both in his Studien zum mittelalterlichen und deutschen Recht (Berlin, 1995), 157-82 and 65-88. My thanks to Stefan Esders for kindly drawing this material to my attention.

${ }^{6} \mathrm{H}$. Mordek, Bibliotheca capitularium regum Francorum manuscripta: Überlieferung und Traditionszussammenhang der fränkischen Herrschererlasse (Munich, 1995) showed the way here. ${ }^{7}$ P. Wormald, 'Introduction', in W. Davies \& P. Fouracre eds., The Settlement of Disputes in Early Medieval Europe (Cambridge, 1986), 1-6, a discussion highly alert to the continental context.
} 
fantasy on the part of the kings issuing them; ${ }^{8}$ they were not a basis for writing social history. ${ }^{9}$

Underneath all this was, perhaps, lay the presuppositions of the English legal tradition itself, built on case law, in contrast to the general principles animating continental jurisprudence.

Reaction has been swift: the law is now back, and with a vengeance. A series of work by younger scholars has insisted upon the possibility, indeed the necessity, of a reconstructed legal history for our period. ${ }^{10}$ In this body of work, the division sometimes presupposed between the ought world (of the lawcodes) and the reality of everyday life (in charters) has collapsed. ${ }^{11}$ Legal norms matter. It is not that they map directly onto behaviour, but they do define worlds of meaning, without which human experience has no shape or form. Social historians cannot simply ignore them in the name of accessing directly what it was really like 'on the ground'. Conversely, how legal norms take shape themselves has to be part of the story: they do not simply emerge fully formed 'top down', or 'bottom up'. Law as it comes into being is a register of need, opportunity, and social negotiation.

Where might this leave us? An unexpected source puts it well:

In any country there is a gap between formal boundaries and reality. But the peculiarity of Italy lies in the exact balance between rival versions of the world, the equal intensity of

\footnotetext{
${ }^{8}$ See P. Wormald, 'Lex scripta and verbum regis: Legislation and Germanic Kingship from Euric to Cnut' in P. Sawyer \& I. Wood eds., Early Medieval Kingship (Leeds, 1977), 105-38; published in the same year and to similar effect, H. Nehlsen, 'Zur Aktualität und Effektivität germanischer Rechtsaufzeichnungen', in P. Classen ed., Recht und Schrift im Mittelalter (Sigmaringen, 1977), 449-502.

${ }^{9}$ See C. Wickham, Framing the Early Middle Ages: Europe and the Mediterranean 400-800 (Oxford, 2005), 830, with the reaction of Lambert, Law and Order, 13.

${ }^{10}$ See e.g. V. Epp \& C.H.F. Meyer eds., Recht und Konsens im frühen Mittelalter (Ostfildern, 2017), in which see esp. S. Esders, 'Zwischen Historie und Rechthistorie: der consensus iuris im frühen Mittelalter', 427-73; K. Ubl, Sinnstiftungen eines Rechtsbuchs: die Lex Salica im Frankenreich (Ostfildern, 2017). In English: P. Dresch \& H. Skoda eds., Legalism: Anthropology and History (Oxford, 2012), and its sequel G. Kantor, T. Lambert, \& H. Skoda eds., Legalism: Property and Ownership (Oxford, 2018). Monographic contributions here include J. Dillon, The Justice of Constantine: Law, Communication and Control (Michigan, 2012); C. Humfress, Orthodoxy and the Courts in Late Antiquity (Oxford, 2007); Lambert, Law and Order; T. Faulkner, Law and Authority in the Early Middle Ages: the Frankish leges in the Carolingian Period (Oxford 2017); A. Rio, Legal Practice and the Written Word in the Early Middle ages: Frankish Formulae , c. 500-1000 (Cambridge, 2009).

${ }^{11}$ Stated with particular clarity by P. Dresch, 'Legalism, Anthropology, and History: a View from Part of Anthropology', in Dresch and Skoda eds., Legalism, 1-38.
} 
people's emotional commitment to private loyalties and moral commitment to public justice. Everyone wants their team to win at all costs and everyone earnestly wishes the world to be fair. It's not an easy state of mind to administrate. ${ }^{12}$

Here Tim Parks is describing what it's like to follow a football team with any commitment: he spent a year as a fan of Hellas Verona, travelling in a bus with other fans to all of their games across the Italian peninsula. Early medieval social actors lived with this difficult state of mind-and on their trail we do the same, trying to administer a methodological field in which we see the law at one and the same time as a product of power relations, and as a cultural force in its own right, setting the terms for experience and giving meaning to behaviour.

The new legal history, to which we seek to contribute here, makes for a more expansive landscape than the old. ${ }^{13} \mathrm{~A}$ traditional account of law in the late and post-Roman world is strongly contoured. There are high points--grand declarations of public justice: the great legal collections of Theodosius and Justinian, and the law-making of Charlemagne-and low points, i.e. anything in between. As we seek to argue here, however, these formative moments are something of an optical illusion: the law is in a constant process of formation and repurposing (Umwidmung), as its shapers and reshapers sought to balance their sense of grievance and entitlement with that of fairness and due process. From this perspective, the legal tradition knows of no Dark Ages.

Our focus is Roman law and Church law in the late ancient Mediterranean and the post-Roman west. For 'Barbarian law', for law in Byzantium and the Islamicate we refer readers elsewhere. ${ }^{14}$ These are

\footnotetext{
${ }^{12}$ T. Parks, A Season With Verona: Travels Around Italy in Search of Illusion, National Character and Goals (London, 2002), 299. Cf. M. Costambeys, 'Disputes and Courts in Lombard and Carolingian Central Italy', Early Medieval Europe 15.3, pp. 265-89, at 289 and n. 106.

${ }^{13}$ For projects looking to offer coverage of the whole period, see, for Roman law Projet Volterra (https://www.ucl.ac.uk/volterra); for post-Roman secular law, Bibliotheca Legum: eine Handschriften Datenbank zum weltlichen Recht im Frankenreich (http://www.leges.uni-koeln.de/); and for canon law, L. Fowler Magerl, Clavis Canonum. Selected Canon Law Collections Before 1140 (Hannover, 2005).

${ }^{14}$ See e.g. Ubl, Sinnstiftungen eines Rechtsbuchs; D. Wagschal, Law and Legality in the Greek East: the Byzantine Canonical tradition, 381-883 (Oxford, 2015); A. El Shamsy, The Canonization of Islamic law: a Social and Intellectual History (Oxford, 2013).
} 
booming fields: by contrast, more remains to be done in the legal history of the family, gender, and sexuality, strong in the late Roman period but less so, perhaps, for the early Middle Ages. ${ }^{15}$

Three interrelated themes emerge here. The first is the role of manuscript transmission in the making of legal tradition. The artificiality of the nineteenth-century typologies has collapsed in the face of scrutiny of the manuscript evidence, which knows of no such tidiness. The law books that have come down to us are dens of hybridity: the search for origins has been replaced with study of tradition-making across the generations.

As a result, the partition between late Roman and early medieval legal culture falls completely. This has long been in sight: twenty years ago, Mark Vessey pronounced that late Roman law is a Merovingian creation. ${ }^{16}$ What he meant by this was that the transmission of imperial lawbooks was the work of sixth- and seventh-century scribes-and we need to know why they chose to spend precious resource on transcribing material compiled for a very different society. Vessey drew attention to one manuscript in particular, a late seventh-century book from Lyons, containing our earliest copy of the Sirmondian Constitutions. He advanced the hypothesis that the Lyons book had been copied from an original made first by bishops assembling for the Second Council of Mâcon in 585. Vessey challenged colleagues to explore this-which is exactly what Stefan Esders and Helmut Reimitz do here.

Meanwhile, Steffen Patzold shows that 'Carolingian legislation' is to an unsuspected degree the creation of the Ottonians in the following century. We have an abiding image of Charlemagne assembling an empire with his warriors through force of will, and then at court with his churchmen

\footnotetext{
${ }^{15}$ On the later Roman world, see e.g. J. Evans Grubbs, Law and Family in Late Antiquity: The Emperor Constantine's Marriage Legislation (Oxford, 1995); A. Arjava, Women and Law in Late Antiquity (Oxford, 1996); K. Cooper, 'Marriage, Law, and Christian Rhetoric in Vandal Africa', in J. Conant \& S. Stevens eds., North Africa under Byzantium and Early Islam (Washington, DC, 2016), 237-249. For the early Middle Ages, see e.g K. Ubl, Inzestverbot und Gesetzgebung: die Konstruktion eines Verbrechens (300-1100), (Berlin, 2008) and work in progress by Steffen Patzold on priests and their families.

${ }^{16}$ M. Vessey, 'The Origins of the Collectio Sirmondiana: A New Look at the Evidence', in J. Harries \& I. N. Wood eds., The Theodosian Code. Studies in the Imperial Law of Late Antiquity (London, 1993), 178-99.
} 
issuing laws to govern his realm. ${ }^{17}$ Patzold shows that this image derives in part from scribes working well over a hundred years later. A number of the capitularies which these Carolingian assemblies issued have come down to us in Ottonian copies. Here, as in the case of Merovingian Gaul, we can reconstruct with some precision the context for manuscript production. That those commissioning manuscripts had precise reasons for shaping a legal claim does not mean that the laws are simply forged-but they may well have been manipulated, and it behoves us to take their Umwidmung into account.

The upshot is that our view of the epoch-making ventures in legal history-the later Roman and Carolingian empires-is refracted through periods thought of as less rich in terms of legal culture. , The Merovingians and the Ottonians, for all the revisionist energy tipped in their direction still suffer a little by comparison. We make the case for their achievements, all the while presuming that they did not obtain levels of literacy and legal accomplishment characteristic of the late Roman and Carolingian periods. This well-meaning sympathy may in fact be misguided: we need rather to appreciate the ways in which these highly sophisticated legal cultures burnished the reputations of the preceding epochs. ${ }^{18}$

Patzold's essay leads onto the second theme, also to do with transmission: the role of 'the provinces.' The efforts of the Rechtsschule notwithstanding, so much of our image of the law turns on a scene of promulgation: rulers like Charlemagne or Constantine laying down the law. This doubtless goes back to Mount Sinai: law descends from the heavens and then descends again from the mountain. ${ }^{19} \mathrm{~A}$ better paradigmatic image would be that of the petitioner (a figure familiar to those who work on charters). Thanks to the work of Fergus Millar in particular, we know that the

\footnotetext{
${ }^{17}$ See now J. Davis, Charlemagne's Practice of Empire (Cambridge, 1915).

${ }^{18}$ See C. Leyser, 'Introduction' in K. Cooper \& C. Leyser eds., Making Early Medieval Societies (Oxford, 2016), 115.

${ }^{19}$ On notions of 'descending' authority, see the work of W. Ullmann, e.g. The Growth of Papal Government in the Middle Ages (London, 1995).
} 
bulk of Roman law is issued in 'response' mode. ${ }^{20}$ The Emperor does not sit down to 'make policy': he acts as a lawgiver when inaction is no longer viable, when the weight of petition is such that ignoring it is no longer politically expedient. When he makes a general pronouncement, it is, on this reading, to forestall a series of future petitions on the same topic. The question is, what happens then: who codifies these rulings? It might be, as we shall see in a moment, a set of legal experts at the centre. But codification could also be a provincial activity--in other words, the work, again, of petitioners. Just as they start the process, so they also receive and codify the rulings extracted from the centre.

The contribution of James Corke-Webster on Eusebius of Caesarea here joins in a remarkable way with that of Patzold in stressing provincial agency. Drawing on recent work, Corke-Webster shows that we have 'misplaced' the bishop of Caesarea. Eusebius may give the impression that he is close to the court-but this is a literary positioning. From his actual base in Palestine, far from the imperial centres of power, he sought in his work to give his readers effective tools in provincial eastern courtrooms. He did so by amassing and artfully arranging the varied legislation of Constantine in the west, as well as that of long-dead emperors whose legislation had gained moral authority as their reputations had grown. Mutatis mutandis, Patzold's capitularists are far in time and space from the Carolingian centres generating the original pronouncements.

Not all codification happened in the provinces. Sebastian Schmidt-Hofner's contribution, and my own, take us to codifiers at the political centre. Schmidt-Hofner's focus is on those in and around the imperial court responsible for the Theodosian Code in the 430s. They were, he shows, inspired by Platonic ideals to embark on the most ambitious work of Roman jurisprudence ever conceived. My

\footnotetext{
${ }^{20}$ F. Millar, The Emperor in the Roman World 31 BC - 337 AD (London, 1992). For a critique, see J. Bleicken, Zum Regierungsstil des römischen Kaisers. Eine Antwort auf Fergus Millar, (Wiesbaden, 1982). Developing Millar's approach are E. Pitz, Papstreskripte im frühen Mittelalter: diplomatische und rechtsgeschichtliche Studien zum Brief-Corpus Gregors des Grossen Papstreskripte im frühen Mittelalter : diplomatische und rechtsgeschichtliche Studien zum Brief-Corpus Gregors des Grossen (Sigmaringen, 1990); and K. Cooper, 'Christianity, Private Power, and the Law from Decius to Constantine', Journal of Early Christian Studies 19: 3 (2011), 327-43.
} 
study turns to the experts in Church law in Rome c. 500, in particular Dionysius Exiguus, who assembled what he envisaged as a definitive collection of canon law. But neither of these projects were exercises simply in the assertion of imperial or ecclesiastical power: they were, like the provincial efforts at codification, attempts to subject power to the rule of law. In the case of the Code, Schmidt-Hofner argues that the highly cultured legal experts were actively at odds with the Emperor himself, as he began to realize that the Code could become a cage restraining his exercise of autocratic power. In Ostrogothic Rome at the turn of the sixth century, canon law as it was emerging betrayed comparable tensions about the nature of law and priestly office-tensions which, I argue, Dionysius sought not to resolve, but to contain.

As the Emperor Justinian of course was to demonstrate, law books could be monuments to autocracy. ${ }^{21}$ But law and its codification could also be the instrument of those without plenitude of power--a weapon of the comparatively weak, designed to create some kind of accountability. If we stand back and survey the period from the Constantinians to the Ottonians, this may be one of the features to stand out. At a moment in our own day when the will to autocratic power is surging, we might savour the irony that the later Roman Empire and the post-Roman kingdoms were arenas where rulers had to reckon with the law, in ways they could not entirely control.

${ }^{21}$ See T. Honoré, Tribonian (London, 1998). 